Article

\title{
Urban Planning for the Integration of Refugees: The Importance of Local Factors
}

\author{
Shahd Seethaler-Wari \\ Socio-Cultural Diversity, Max-Planck-Institute for the Study of Religious and Ethnic Diversity, 37073 Göttingen, Germany; \\ E-Mail: wari@mmg.mpg.de
}

Submitted: 16 July 2018 | Accepted: 5 September | Published: 20 December 2018

\begin{abstract}
Housing location is one of several characteristics that play a significant role in the future integration of asylum-seekers. Many of these characteristics or institutional arrangements are spatialized aspects relevant to urban planning. Drawing on experiences from fieldwork in Göttingen, a mid-sized city in the German Federal state of Lower-Saxony 2016-2018, this article demonstrates the local challenges, strategies and their resulting institutional arrangements on various aspects of asylum-seekers' lives. It discusses the influence of those arrangements on the development of their social circles, and on their access to different resources, influencing their participation in and interaction with the social and urban life of their host cities; thereby influencing their integration processes. To do so, the article addresses local factors that are significant for urban planners to include into an integration plan. It observes the role urban planning can play in preventing aspects of segregation in the various life domains of refugees and in providing urban contexts that facilitate integration in European cities. The first assumption of this article is that integration, refugees' attitudes towards it, and an urban context that can facilitate it start from day one of the arrival of new comers in their host city/town. The second assumption is that integration happens on the local level of the city, and more specifically on the level of the host neighborhood.
\end{abstract}

\section{Keywords}

accommodation; asylum-seekers; Germany; housing; refugee; segregation; urban planning

\section{Issue}

This article is part of the issue "European Cities Planning for Asylum", edited by Frank Eckardt (Bauhaus-Universität Weimar, Germany).

(C) 2018 by the author; licensee Cogitatio (Lisbon, Portugal). This article is licensed under a Creative Commons Attribution 4.0 International License (CC BY).

\section{Introduction}

This article aims to present parts of the German experience in refugee reception and accommodation. It draws on the fieldwork and preliminary findings of a research project implemented in the city of Göttingen, a mid-sized city in Lower-Saxony. The project was launched at the Max-Planck-Institute for the Study of Religious and Ethnic Diversity in February 2016 with the financial support of the Volkswagen foundation. It aimed to study the diversity of needs and aspirations of new comers (i.e., asylum-seekers arriving in Germany since 2015). It also investigated the responses of the German state and nonstate institutions, to these needs and to the so-called "refugee crisis" in general. The fieldwork was carried out by a multi-disciplinary team of three post-doc researchers: a sociologist, an anthropologist, and an architect/urban planner (the author).

The project employed a mixture of ethnographic and other qualitative methods including; participant observation in refugee accommodations and in public meetings and events; focus group discussions; hangingout (Geertz, 1998) and informal meetings with asylumseekers and recognized refugees; semi-guided interviews with asylum-seekers, practitioners in different city institutions, social workers, volunteers, and management staff members (Betreiber) of selected accommodations. This is in addition to participatory research methods like language portraits and Photovoice. The data is coded and analyzed inductively, with the help of qualitative data 
analysis software (Vertovec, Becker, Fleischer, Schader, \& Wari, 2017).

Through the lens of ten refugee accommodations in Göttingen, and based on the fieldwork's preliminary findings, the article aims to highlight the local factors found significant to include in an integration plan from an urban planning perspective. These factors have three aspects: challenges related to the local host environment and urban planning in general; the characteristics of refugee accommodations - that this article will refer to as institutional arrangements (Vertovec et al., 2017) - responsible for differential access to services and resources; and the diversity and personal experiences of the refugee population hosted on the local level. Those local factors, it is argued, play a central role in the development of trajectories of "integration" ${ }^{1}$ of asylum-seekers and refugees in their host (receiving) cities.

The article starts with two assumptions. The first is that integration, refugees' attitudes towards it, and the urban context that can facilitate or hinder it start from the first day of the arrival of new comers in their host environment. The second assumption is that integration happens on the local level of the city/town, and more specifically on the level of the host neighborhood (Fonseka \& McGarrigle, 2012; Hinze, 2013; Wari, 2017; Wiesemann, 2011). The article argues for the importance of the local in the planning and implementation of integration strategies in an early phase of reception and accommodation, and for the importance of thorough consideration of the role that institutional arrangements of refugee accommodation play in the long-term integration of refugees.

Germany has a Federal decentralized system of politics, administration and urban planning (Pahl-Weber \& Henckel, 2008). In the reception, accommodation and integration of refugees, different levels of the state have different tasks to fulfill. The macro national level decides how to disperse refugees to different states. Federal states (Länder), the executive arm of the government (Hooper, 1988, p. 184), decide how refugees are distributed between their different cities and communities, and partly cover costs that refugee accommodation generates on the local level (Katz, Noring, \& Garrelts, 2016). However, integration happens on the local level (Kronenberg, 2018). Cities and towns host refugees (Ray, 2003), decide the location and characteristics of refugee accommodation, offer German and integration courses, and support refugees to find housing, trainings and jobs.
It is also the local civil society (engaged neighbors, volunteers, and sponsors) that contributes to building social circles and acting as links between the new comers and the host society (ESPON, 2015).

Within this decentralized federal system, urban planning systems (Le Galès, 2003) work differently in the different federal states, even in different cities and communities. While some cities have built-in urban planning departments, others do not; urban planners have different levels of authority and access to resources in different cities (Schiller, 2018); and the land uses of some cities are further planned than others (architect, personal communication, June 2018). Therefore, decision-making processes, urban planning cultures and systems are different from one city to another.

In the so-called "refugee crisis"2 of 2015, a relatively large number of asylum-seekers was arriving in Germany in a short span of time. They were received and accommodated in reception facilities before they were distributed across the country according to the quota decided by the Königstein key (see Section 2). The different states received asylum-seekers and distributed them to their allocated cities or towns. In the beginning of the refugee influx, many cities, including Göttingen, had announced their intention to avoid camp structures like tents and sport halls, and to accommodate asylum-seekers and refugees in decentralized housing. However, in light of the numbers of arrivals, most cities were not able to keep up with their initial intentions. At the peak of that phase, many administrative staff members in German cities felt overwhelmed by the situation (administrative staff, personal communication, May 2016) where they had to find prompt solutions to accommodate newcomers. These decisions were made spontaneously with the main concern to provide a "roof over their heads" and to meet their basic immediate needs. Therefore, it was mostly existing structures, like sport halls, old schools, and factories that were transformed to temporary accommodation centers in the first phase of the "crisis".

While the numbers increased, planning and construction of purpose-built structures to accommodate asylumseekers became a necessity for lack of decentralized and social housing. Modular housing projects and container villages started to appear in many German cities, joining the existing transformed structures. Asylum-seekers should live in these for a theoretical maximum period (from three months to four years) depending on the

\footnotetext{
1 "Integration" is a contested and highly debated term among academics, policy-makers and civil society groups, and is surrounded by massive literature (inter alia, Alba \& Foner, 2014; Bommes, 2007; Castles, Korac, Vasta, \& Vertovec, 2002; Esser, 2006; Hess, Binder, \& Moser, 2009; Loch, 2014; Mecheril, 2011; Schönwälder, 2013; Vertovec, 2011; Wieviorka, 2013). The term is often criticized for conveying presumptions that, through a singular process, outsiders become accepted into a pre-existing society that is imagined to be homogeneous. These presumptions run counter to much sociological theory. While sharing such terminological and conceptual criticism, for the purposes of this article, the use of the term "integration" is meant as an umbrella for a broad range of processes. These include the acquisition of German language; gaining access to work, housing, education and training; building social contacts and networks; participation in representative politics; respecting national law and legal authorities; and the adoption of certain civil and cultural practices and values.

2 "Refugee crisis" is the term used in European media and by politicians to describe the increase in numbers of asylum-seekers arriving to Europe, which reached a peak in the second half of 2015 and beginning of 2016. However, statistics provided by EUROSTAT (2016) challenge the rhetoric that there is a "crisis" in the sense that the developed European Union would be overwhelmed by the numbers of asylum-seekers (0,2\% of the EU population), especially when comparing those to the developing countries which took in much larger numbers and percentages of asylum-seekers.
} 
regulations of different federal states (Wendel, 2014). This period was extended after the failure of many cities to accommodate their share of refugees in decentralized housing fast enough. In public information events for the locals, there were two main arguments that accompanied purpose-built solutions; that they are temporary and would be removed after all asylum-seekers have moved out, or that they were planned for other uses in the long term, like being made available on the social housing market or as student accommodations. These claims may or may not be realizable, depending on the institutional arrangements of each housing solution, whose role in the daily lives and integration of asylumseekers and refugees is the main focus of this article.

The article is divided into two main sections; the next section addresses recent measures of dispersal and integration in the German context and on the local level of Göttingen, and the following section discusses the three aspects of local factors relevant for urban planning and its role in refugee integration.

\section{Measures of Dispersal, Accommodation and Integration}

\subsection{The National Level: Germany}

Concerning European integration policies, a main similarity among European countries is that integration becomes a concern in a later stage of settlement, after reception, accommodation and recognition of asylum rights (Ager \& Strang, 2008, p. 79; Poteet \& Nourpanah, 2016; Scholten et al., 2017), which ends with a legal status and residency permit. For asylum-seekers, this is a long process of waiting (Scholten et al., 2017), which lasts several months, if not years. However, some integration measures have been implemented earlier on the local level of some European and German cities, especially within refugee accommodations by their management staffs and volunteers, in an attempt to start the integration process faster.

Germany has not considered itself as a migration country until the beginning of the 2000s (Chin, 2007). Therefore, institutionalized policies of integration are a recent development in the German context (Gesley, 2017). In August 2016, the new integration law (Integrationsgesetz) was enforced (The Federal Government, 2016), adding restrictions on the movement of refugees from their allocated federal states for a minimum of three years (Wohnsitzauflage) (unless they have a job contract or seat at an educational institution in other states). This new regulation is considered central to German integration policies (Renner, 2018) by avoiding the concentration of refugees in big cities, which are usually more attractive for migrants and refugees (ESPON, 2015, p. 2). This is due to better job opportunities, the presence of past migrant populations and potential social networks (Brezzi, Dumont, Piacentini, \& Thoreau, 2010). By dispersing refugees, German policies aim to prevent eth- nic segregation, and the formation of so-called "ghettos" and "parallel societies", issues that are considered a concern in the current public discourse. Critics of this law insist that these policies would hinder the integration of refugees who have existing social networks in other federal states that could serve as main actors in finding housing and job opportunities thereby accelerating their integration processes. Until the first quarter of 2018, only seven of the 16 federal states have chosen to apply the Wohnsitzauflage (Renner, 2018) and restrict the relocation of refugees to other federal states.

Each German Federal State receives a percentage of asylum-seekers based on the Königstein key (BAMF, 2016), a quota system that is (re)calculated annually based on the size of state populations and their income from tax returns (see Figure 1). This quota system aims to share the responsibility and costs of accommodating and integrating asylum-seekers and refugees. However, it has been criticized (Katz et al., 2016) for ignoring more important aspects to make this possible like, the land resources of the different federal states (especially relevant for city states), and the state of their cities' infrastructures and job markets (especially important in shrinking cities and rural areas).

Other aspects of integration, in the German context, include language courses, job market integration, housing, education, social and cultural integration, supervision and consulting, health, sport, and cultural diversity (Renner, 2018). Although all aspects are important for "successful integration", this article focuses especially on the role of housing from the temporary accommodation phase, because of its central role in accessing various other integration aspects, and access to information, resources and social networks.

In European and German cities, a huge range of local active actors was involved in the reception, accommodation and implementation of integration measures. The civil society including NGOs, welfare organizations, academic and cultural institutions, and volunteers played a central role in this process. Therefore, access to social circles among locals and local civil society is significant for supporting and facilitating trajectories of integration, and for avoiding segregation in various life domains (van Ham \& Tammaru, 2016). This access is necessarily influenced by the combination of institutional arrangements at a given accommodation.

\subsection{The Local Context: Göttingen}

By the end of 2016, the city of Göttingen had a total population of some 134,000 (GÖSIS, 2016). That year, it had received 1,366 asylum-seekers from tens of countries, with the biggest groups of nationalities from Syria, Afghanistan, and Iraq. The percentage of foreigners in the city had constituted $13 \%$, which included international students, migrants and newly arrived asylum-seekers. Of the total number of asylumseekers in Göttingen, $67 \%$ were male and $33 \%$ were fe- 


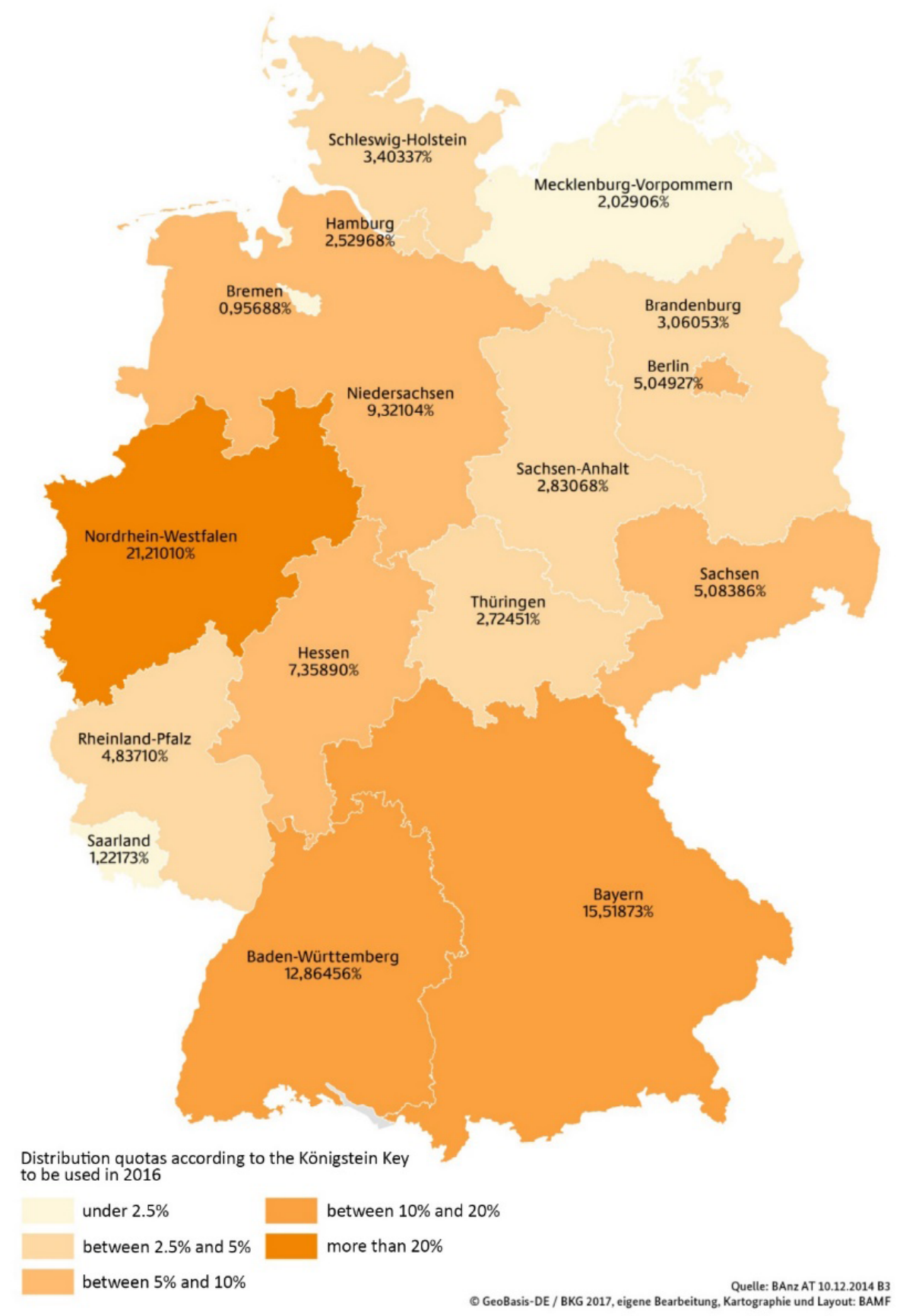

Figure 1. Refugee distribution quotas, in German federal states, according to the Königstein key in 2016. Source: translated from BAMF (2017, p. 17).

male. Moreover, $28 \%$ were aged under $17,42 \%$ between 17 and 30 , and $30 \%$ were over 30 years old (GÖSIS, 2016).

Known for its prestigious university, students constitute a substantive number of the 18-30 age group, which constitutes $27 \%$ of the population (GÖSIS, 2016). Together with students and academics working at the university and several academic and research institutions, asylum-seekers added to the high demand and pressure on housing in a city that already had a social housing problem.

Having a visible antifascist movement, Göttingen is popularly known as a "leftist" city that is more welcom- ing of migrants and refugees, than smaller towns in the Göttingen district and other districts in Lower-Saxony, as Figure 2 illustrates. In its housing and integration concept in 2014 , the city shares its assumption that the majority of hosted asylum-seekers would remain in the city and that it therefore supports their integration measures from the beginning (Stadt Göttingen, 2014, p. 3) through language classes, education, and integration into the job market and society. However, not all decisions made regarding refugee accommodation and their resulting institutional arrangements were made to facilitate integration trajectories. 


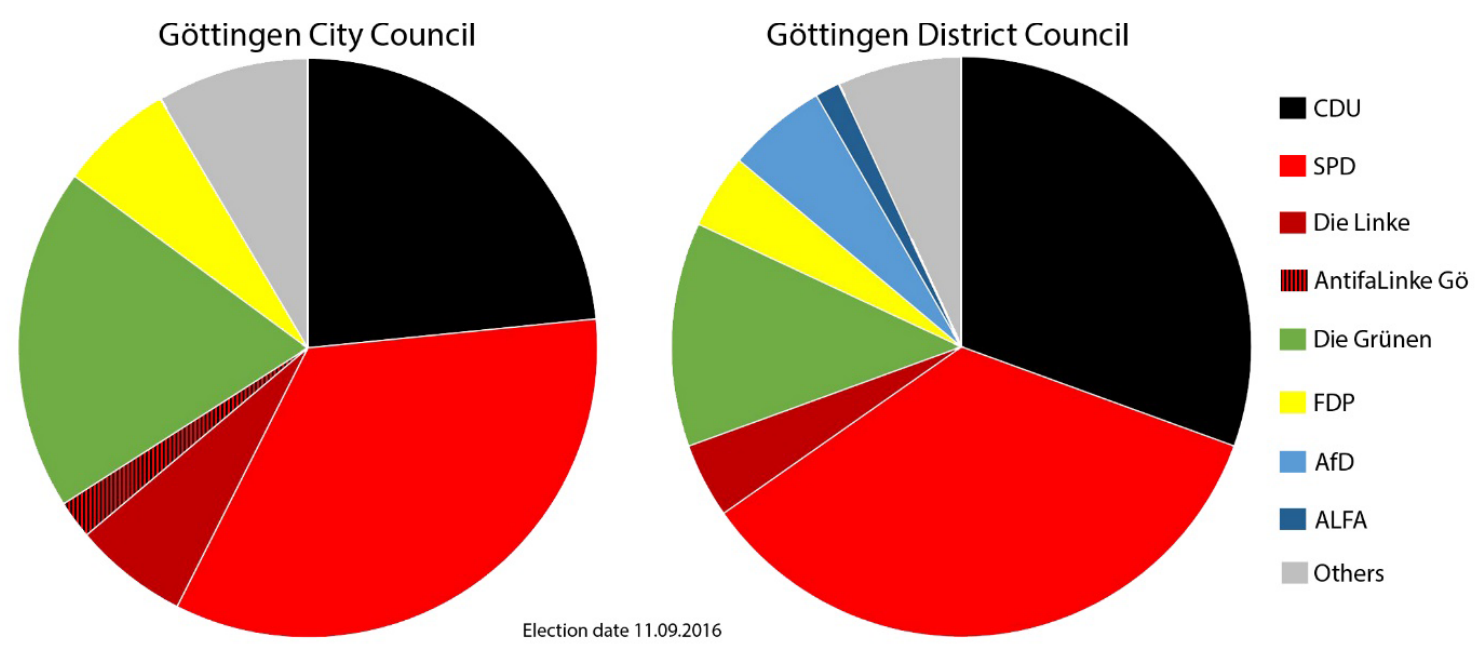

Figure 2. Comparison of political parties' seat distribution in Göttingen City and district councils in 2016. Source: author, based on data from Stadt Göttingen (2018a) and Landkreis Göttingen (2018).

Overall, between autumn 2015 and June 2018, the city of Göttingen received 2,880 asylum-seekers (Stadt Göttingen, 2018b). Through the city administration, social workers and the engagement of volunteers, 1,620 asylum-seekers and refugees were able to find decentralized housing. However, and despite a 19 Million Euros investment by the Municipal Housing Construction Society, for the provision of housing possibilities, 1,260 asylum-seekers still live in refugee accommodations (Stadt Göttingen, 2018b). Some of these cannot find housing due the lack of suitable units/apartments in the German housing market (e.g., units appropriate for families with more than three children, which is a need of many refugee families).

\section{Local Factors Significant for Integration Plans: An Urban Planning Perspective}

\subsection{The Role of Urban Planning Systems in Refugee Accommodation: Local Challenges}

The multi-layered multi-disciplinary aspect of urban planning involves different understandings of planning discourses and concepts and leaves a wide scope for interpretation by planners and decision makers (e.g., politicians, administrative staff members, professionals and practitioners) in different planning systems (Le Galès, 2003) and cultures (Othengrafen, 2012). This, the author argues, is especially true for those involved in the reception, accommodation and integration of asylum-seekers and refugees, especially considering that planning for integration remains a weak legal concept and still needs a lot of work by urban planners and planning systems (Othengrafen, 2012).

In the polycentric German system (Strubelt, Gatzweiler, \& Kaltenbrunner, 2000), urban and spatial planning provides a huge scope for decision making on the federal, regional and local levels. It is the local level of municipalities, for example, that plans urban develop- ment and land-use and decides the locations and characteristics of refugee reception and accommodations. In this decentralized context, cities in the different federal states-and based on their different profiles, have different municipal structures, positions and hierarchies of urban planning departments.

The project's empirical findings in Göttingen confirm that for issues related to asylum-seeker reception and accommodation between 2015 and 2016, most decisions were taken by politicians and administrative personnel. This is because the time pressure of new arrivals would leave little time for the slow bureaucratic procedures of planning (urban planner, personal communication, September 2017). Generally, trained urban planners may have been consulted at times, but their recommendations were not necessarily followed by decision makers (e.g., Schiller, 2018). Several challenges on the local level played a role in the way such spontaneousand sometimes ad-hoc-decisions were made to accommodate asylum-seekers in the short-term, which largely influence the long-term integration dynamics of refugees (Poteet \& Nourpanah, 2016).

Based on the position of the decision maker on the local level, some aspects like political orientation, voter preferences, implementation speed, or budget allocations may be prioritized in their decision-making processes, over other aspects important for the long-term development and integration recommended by experts and urban planners. These decisions, nonetheless, influence the urban context on multiple levels and affect the socio-spatial tissue of the urban context.

Urban planning decisions are naturally political, and regardless who takes them, they face many challenges in the context of refugee reception and accommodation. Most challenges are not created by the refugees, but by existing structural problems (Lindley, 2014) and a housing crisis (Penny, 2016) that were revealed by the instant need for housing solutions by asylum-seekers and refugees. Examples of such challenges are: uncer- 
tainty of number of arrivals/remaining asylum-seekers; existing shortage in social housing; budget allocation; access to land resources and private land ownership; state of infrastructure; land designations and land use; timeconsuming bureaucratic procedures; availability and commitment of construction workers; voter preferences and nimby (Not In My Backyard) dynamics; marginalized migrant neighborhoods and "social burning points"; and adequate apartment sizes for bigger families. Those local challenges related to the host environment complicate decision-making processes.

In addition to these challenges, the diversity of hosted asylum-seekers and the institutional arrangements of their accommodations, are significant in the development of their integration trajectories on the local level and should therefore be taken into consideration when planning for integration. The following section addresses selected institutional arrangements and their role in the daily lives of asylum-seekers and refugees and illustrates how they may facilitate or hinder efforts of integration, or even result in exclusion and segregation.

\subsection{Spatial Institutional Arrangements and Their Effects on Trajectories of Integration}

Different German cities received and accommodated asylum-seekers in a wide range of accommodations. From emergency reception centers to purpose-built container villages, the spectrum of host structures provides a unique combination of institutional arrangements in each accommodation. These combinations allow different levels of access to various resources and services and confront asylum-seekers and refugees with different levels of complexities in their daily lives, influencing their individual trajectories of integration differently. While the institutional arrangements surrounding their accommodation may accelerate the integration process for some, it may hinder or decelerate it for others. The consequences of this are not only short term while they reside in the accommodations, but also extend into their future in Germany after they leave the accommodations.

Many of these institutional arrangements are spatial in nature, which are relevant to urban planning and architecture. Therefore, both disciplines can play a significant role in facilitating integration processes of asylumseekers in host cities, if these arrangements are included and considered while planning for integration. The spatial institutional arrangements presented below play a role in the temporal patterns of asylum-seekers' daily lives; they influence with whom they live, whom they meet, and the social circles and networks they can create on the local level with German locals, other asylumseekers or old migrants. In addition, they play a role in the selection of people with whom they eventually socialize, work, and commute. This directly influences how smooth their trajectories progress, and whether they lead to integration or segregation.

\subsubsection{Accommodation Location}

\subsubsection{Proximity to City Center}

Inhabitants of accommodations located in or close to the city center (see Figure 3 ) have easier access to urban services and infrastructure, shorter commute duration to reach city institutions, and are more likely to leave their accommodations and interact with their cities' public spaces, parks and enjoy leisure activities. Centrality is also fundamental in encouraging many volunteers to engage in accommodations thus playing an active role in the lives of asylum-seekers and widening their social networks and support systems.

In contrast, the accommodations located further (more than $2 \mathrm{~km}$ ) outside the city center have limited public transport possibilities and longer commutes. This makes the trips to the city harder and discourages asylum-seekers (with a few exceptions) from leaving their accommodations if they did not have specific errands to run. More importantly, such locations discourage the engagement of active volunteers, thus limiting asylum-seekers' access to German courses and interaction with locals, and access to social and free time activities, a much-needed distraction in their phase of constant waiting (e.g., waiting during the asylum process, for a legal status, to find housing, to find jobs, for family unification and for a normal life to start).

\subsubsection{Direct Surroundings}

The location of accommodations is not only important in terms of distance or proximity to the city center, but also in terms of the direct surroundings on the neighborhood level.

Different accommodations have different surrounding environments. Whether old transformed structures or newly built housing projects, some are located within residential neighborhoods (e.g., Figure 4) and others are isolated in industrial or commercial areas (see Figure 6), lacking social spaces that allow for contact and exchange with willing neighbors.

For those located in residential neighborhoods, a layer of "normality" is added to their lives. However, there are additional aspects to take into account by way of planning systems, like the socio-economic level and the socio-political profile of different neighborhoods and their inhabitants. These, for example, play a role in the kind of contact that results with the neighbors. In Göttingen, middle-class neighborhoods generally provided a welcoming atmosphere and engaged neighbors in the lives of "their refugees" or "their accommodations", as they referred to them. They served as volunteers, German teachers and sponsors (Paten) of individuals and families. With this engagement, the refugees were located in an urban context that allowed them contact and facilitated their interaction with the local host society helping both sides to learn more about their re- 


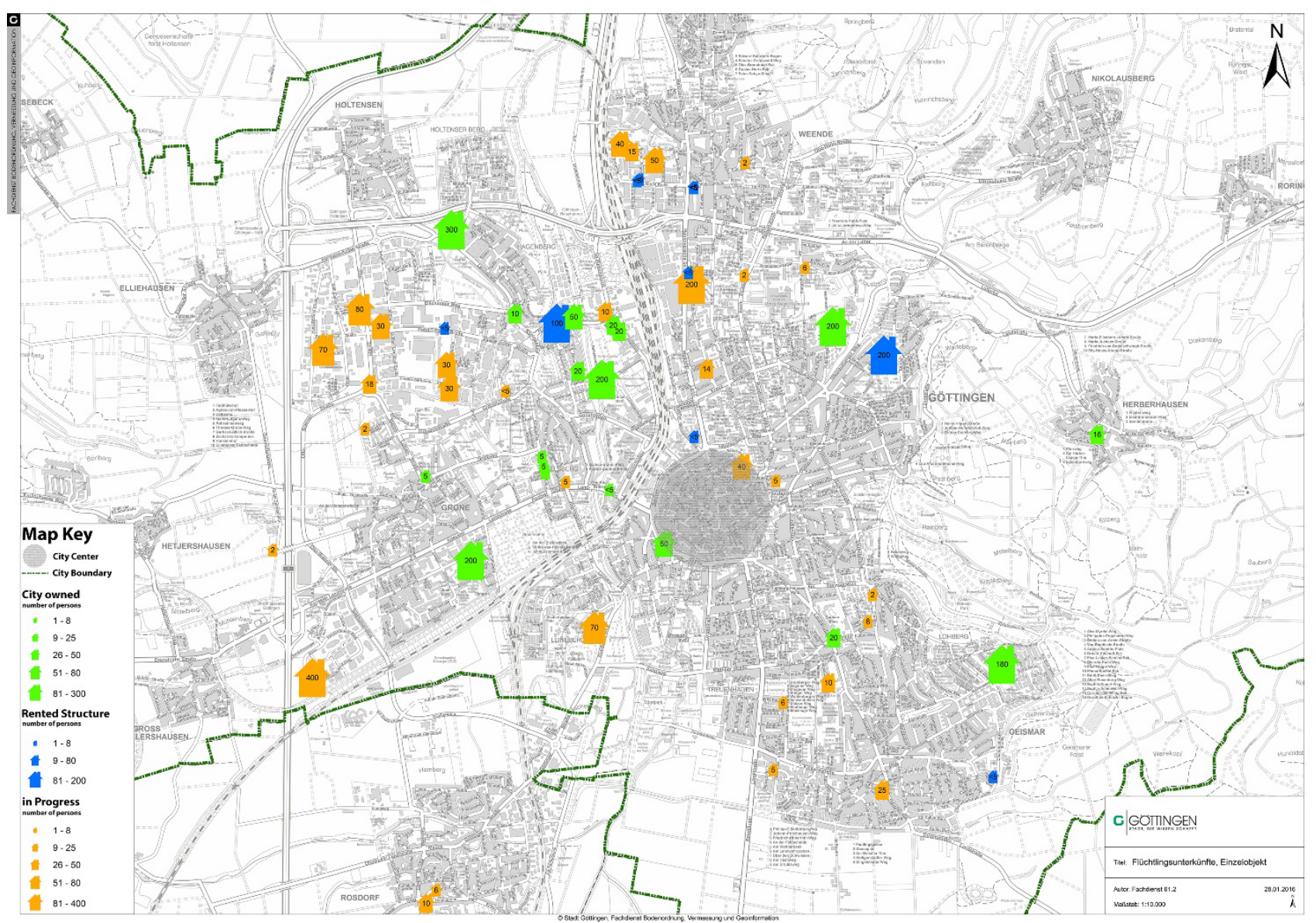

Figure 3. Refugee accommodations' sizes and distribution in Göttingen in 2016. Many have been closed since. Source: translated from the plan published by the Göttingen City website in 2016.

spective "cultures". In contrast, economically struggling neighborhoods, with an already high share of migrants, lower quality of infrastructure and higher competition over services were more vocal in criticizing the city's decision to locate refugee accommodation in their neighborhoods. In one such case, the planner/architect took a back-to-back planning approach (Khamaisi, 2006), designing a U-shaped accommodation/housing project to face the highway (see Figure 5) with its back to the adjacent neighborhood, resulting in a space that separates its 300 inhabitants from their residential surroundings, and lacks engagement with the neighborhood.

This observation in Göttingen cannot be generalized. Richer neighborhoods in Hamburg, for example, were more aggressive in protesting against planned refugee accommodation projects than economically struggling neighborhoods with a high share of migrants (Drieschner, 2016). This illustrates the uniqueness of towns and cities, especially on the neighborhood level, and supports the article's argument to plan for integration locally.

\subsubsection{Centralized and Decentralized Accommodations}

Whether refugee accommodations are centralized or decentralized, is another significant arrangement in the first phase of reception and accommodation. While centralized managed accommodations impose more control and lack of privacy on their inhabitants, they have full or part time staff whose main task is to support asylumseekers with their daily lives. Although with differential quality, most centralized accommodations in Göttingen offer free access to internet, translation services, help with asylum forms and procedures, regular donations, information about city and free time activities, and a number of committed volunteers. On the other hand, decentralized housing solutions offer aspects of normality and independence that most refugees crave after the first phase. However, and although most existing literature argues for decentralized accommodation as the better solution for integration of refugees, some of our informants, who were accommodated in decentralized housing from the beginning, reported that they felt isolated from other refugees. They had no free access to internet, no contact with volunteers or locals, limited access to donations and lack of information about free time activities in the city. This restricted their access to resources and services, thereby limiting their interaction with the urban environment and decelerating their integration process.

This example is not meant to "romanticize" centralized accommodation, but to illustrate how important ac- 


\section{COGITATIO}

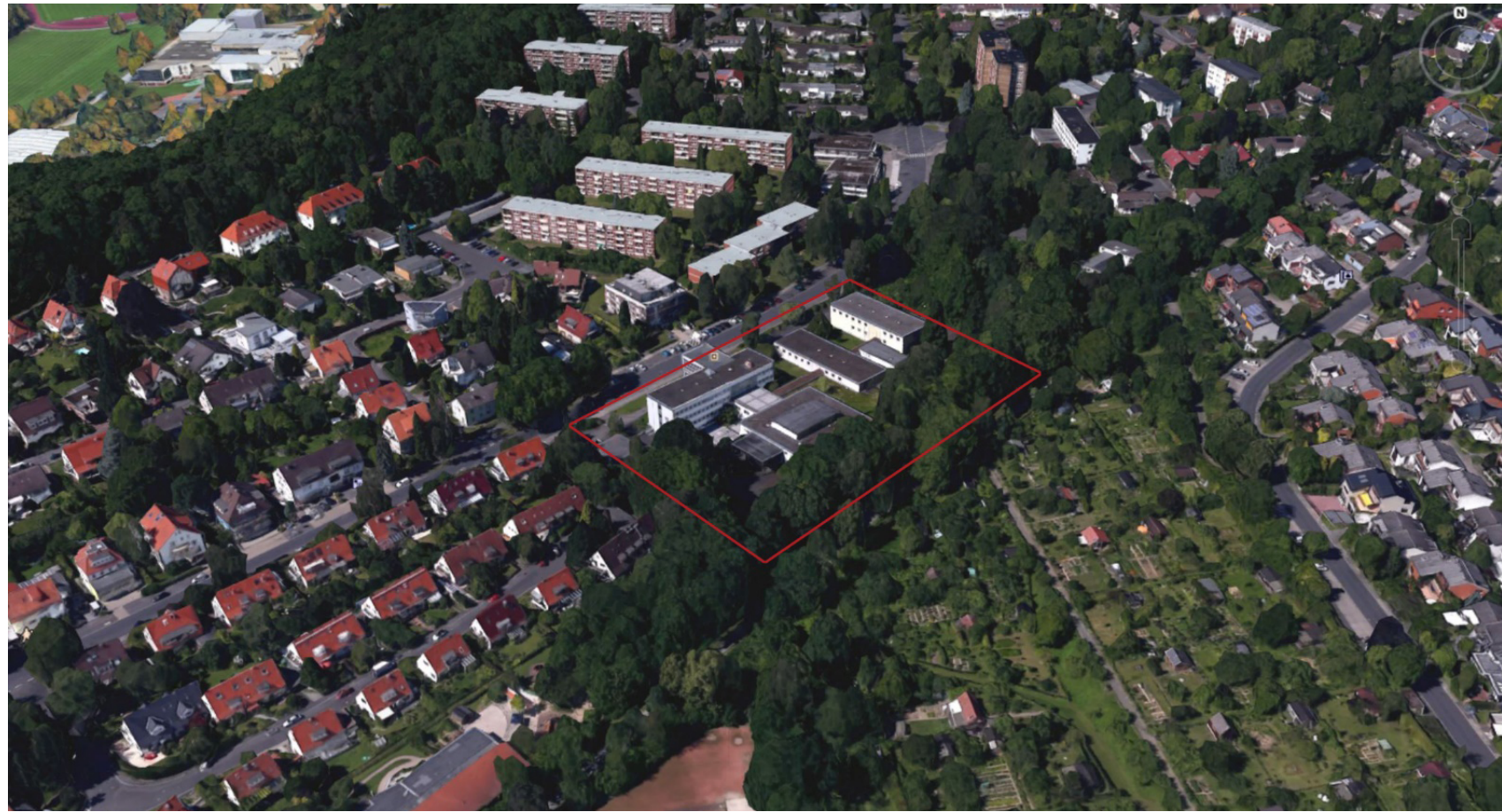

Figure 4. Former institute transformed into accommodation for 200 asylum-seekers in 2015. The accommodation, located in a residential neighborhood, enjoyed high engagement of neighbors and volunteers before it was closed. Source: author. Aerial view retrieved from Google Earth on 31 October 2018.

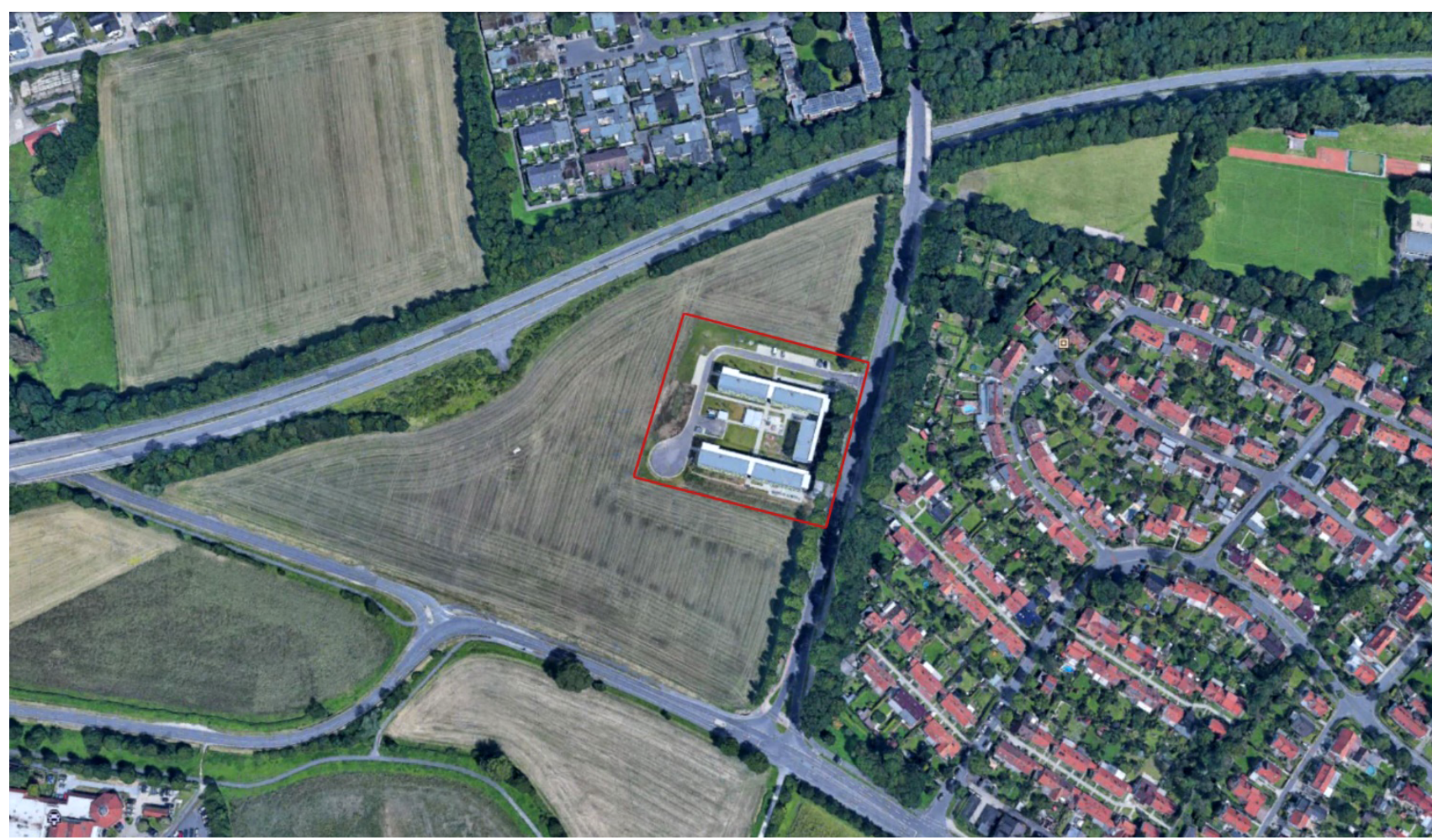

Figure 5. Purpose-built refugee accommodation/housing project, designed with five buildings and six-person apartments. Source: author. Aerial view retrieved from Google Earth on 31 October 2018.

cess to resources and services are for the trajectories of refugee integration. It is also important to point out that there is no best solution, that fits all refugees or all cities, and that the combination of institutional arrangements at a given accommodation is more relevant than single characteristics. The personal background of individual refugees, their education levels, the languages they speak, the time they had already spent in their host en- 
vironment, their priorities and preferences, and their social networks significantly determine what type of earlyphase accommodation would best facilitate their integration in the long term. However, concrete awareness about this refugee diversity presents an additional challenge to decision makers and planners.

\subsubsection{Accommodation Size}

The size of refugee accommodations serving as temporary or permanent housing solutions influences their access to resources and services. In Göttingen, the range of accommodation sizes is so wide that some structures accommodate two while others have the capacity to accommodate up to 400 asylum-seekers (and up to thousands in other cities). Such accommodation structures usually offer shared sanitation services like bathrooms and kitchens or canteens, which limits the freedom, comfort and privacy of asylum-seekers and prevents them from place-making and feeling "home". Big accommodations also increase the potential for social control, conflicts over the use of those spaces (Christ, Meininghaus, \& Röing, 2017; Engelmann, 2018), or conflicts due to different hygiene standards and habits among different individuals and groups. Smaller accommodations offer higher levels of freedom, comfort and privacy, but still lack normality, an important need that our contacts iterated, and an important basis for integration, espe- cially for vulnerable and potentially traumatized groups (Black, 2001).

On the other hand, the size of the accommodations is decisive in the development of social networks and relationships among the inhabitants, management staff and volunteers. The larger the group of asylum-seekers living together in the first phase, the bigger the spectrum of people, cultures and experiences to exchange with and chose from to build more beneficial social networks. However, the fact that refugees live in allocated accommodations, big or small, already decides which people they get to meet and with whom they would communicate in that life domain (van Ham \& Tammaru, 2016).

\subsubsection{Spatial Layouts}

While some converted warehouses, sport halls or old schools and factories were able to provide instant "roofs" for many people in a short time, their spatial layouts and architectural designs are not meant for housing and living purposes. Suitable room designs, sizes, and other living spaces are mostly unavailable in such structures. For large spaces divided by partitions that accommodate six to 14 persons (see Figures 6 and 7), additional obstacles to normality are present like the high density in the rooms, constant loud noise, lack of control over lighting and ventilation, of freedom, privacy and independence in daily life activities. Such structures limit the

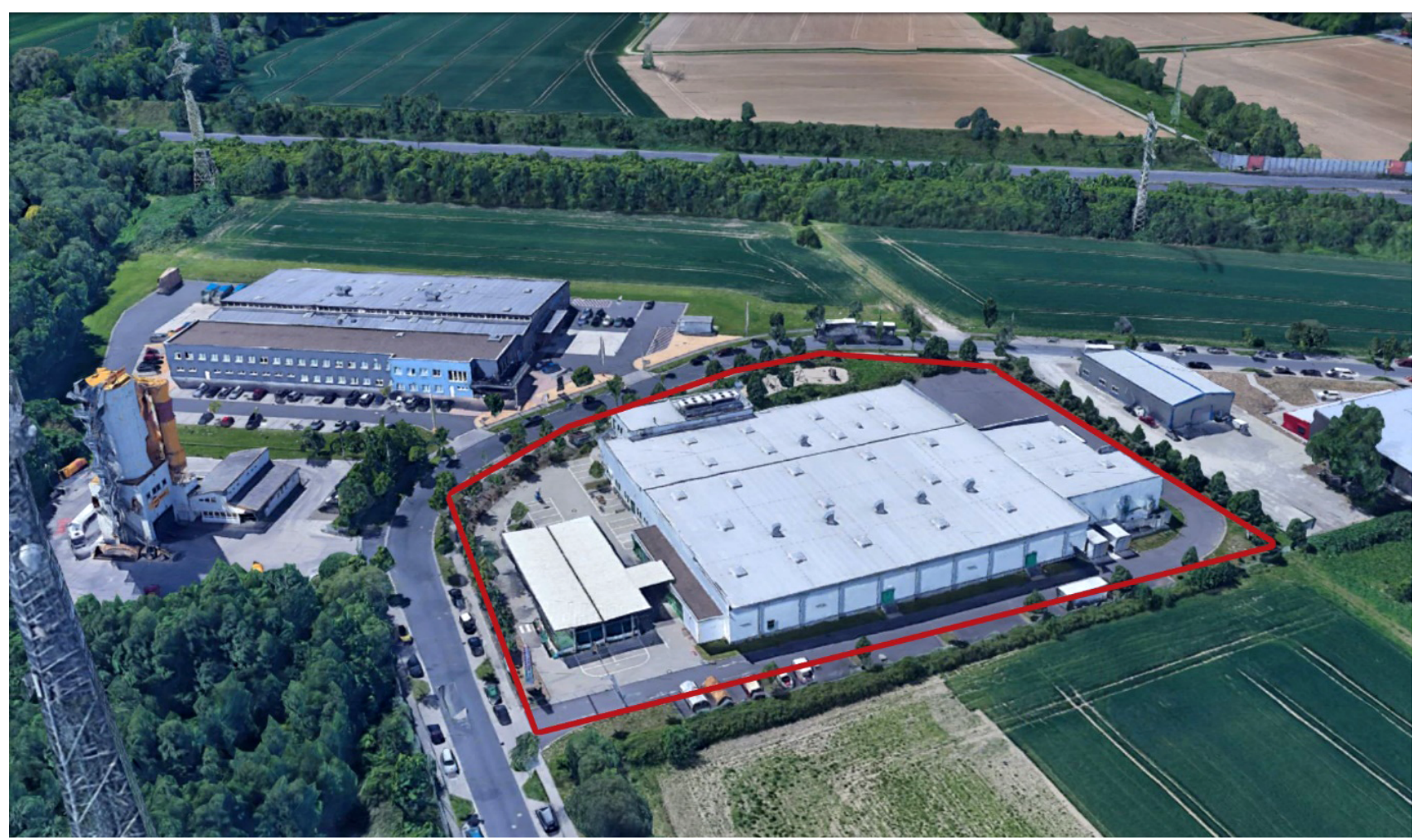

Figure 6. Former market hall transformed into a refugee accommodation for 400 persons. Most recently, it has been used for rejected or tolerated asylum-seekers or those with a low recognition profile. The structure located in an industrial area is close to the highway and has no windows. The next figure illustrates the interior. Source: author. Aerial view from Google Earth on 31 October 2018. 

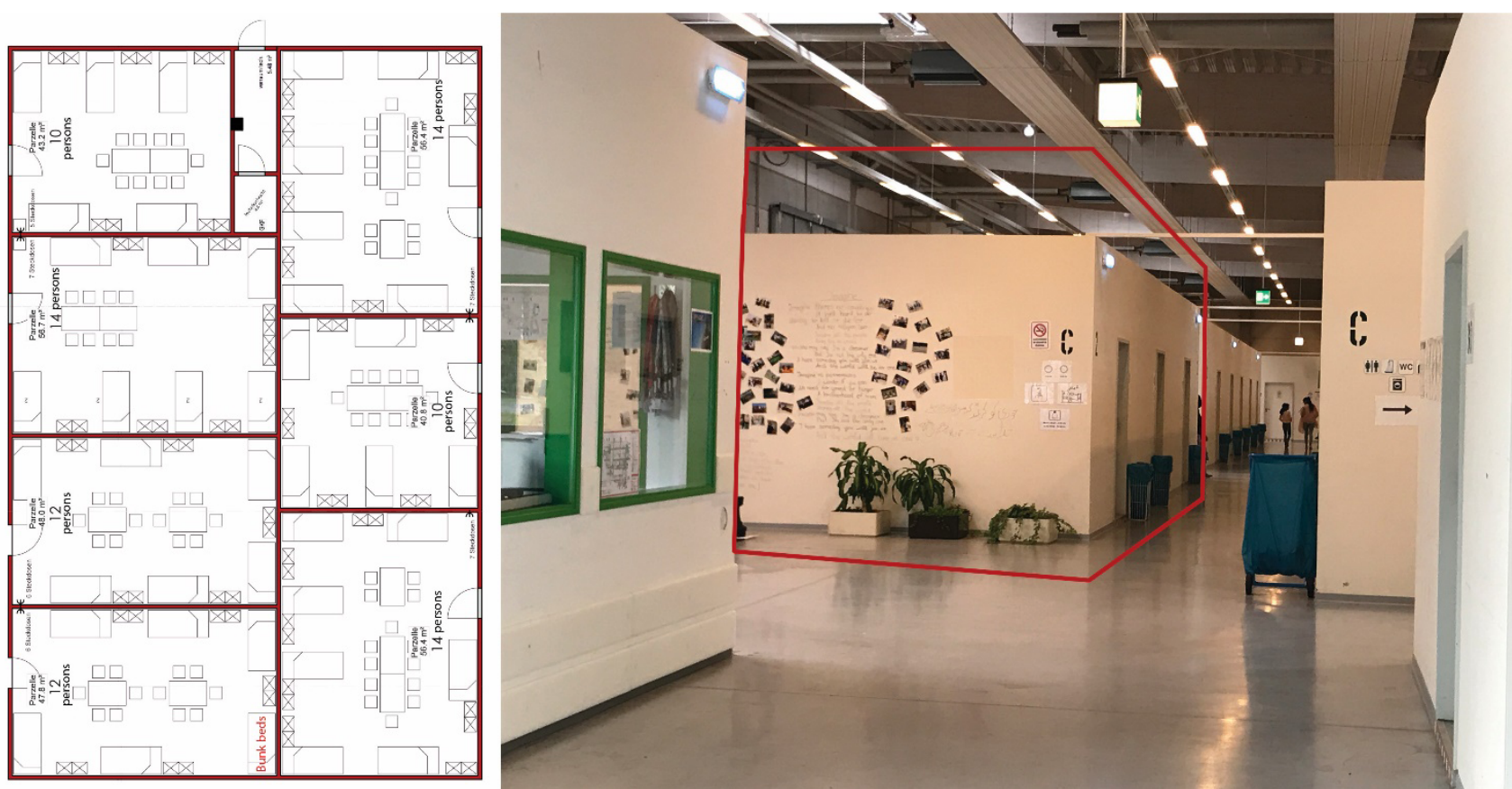

Figure 7. Right: interior of accommodation hall with its partitioned blocks. Left: floor plan of one block, as marked on the right. The partitions (rooms) accommodate between ten and 14 persons. Sources: author (right); edited from a floor plan published in the Göttingen City website in 2017 (left).

possibility of withdrawal, relaxation, sleep, and make private chats with friends, phone conversations with family members, or focusing while reading or studying difficult. The fact that some of these structures have no windows was reported to give asylum-seekers the feeling that they are in a prison. This feeling is further exacerbated in fenced structures that are constantly manned by security personnel.

The existence and layout of entrances, meeting areas, and cooking spaces are also important factors that differentiates aspects of daily lives of asylum-seekers and refugees who live in refugee accommodations. In very large accommodation structures (especially transformed halls or warehouses), cooking facilities are not part of the layout design, and catering services are the only option. So, in addition to sharing toilets and bathrooms with tens or sometimes hundreds of people, some asylum-seekers are deprived of the freedom to cook and eat what they want, when they want, and/or are prevented from inviting friends and acquaintances for a private meal, another central social activity that many asylum-seekers miss as part of a normal life.

Furthermore, public spaces, gardens, playgrounds, prayer rooms, smoking spaces, or meeting facilities, which the inhabitants can use to meet, socialize, or carry out free time activities are important for the social and mental health of asylum-seekers. Such spaces exist in different quantities and qualities in different accommodation centers. However, many accommodations-in which asylum-seekers may spend their first months or years-offer limited possibility for inside or outside activities. In one accommodation center, asylum-seekers used to spend their free time on the sidewalks in front of the accommodation to socialize or smoke, thereby blocking the sidewalks or talking loudly, which resulted in complaints and frictions with neighbors and passers-by, which added to their feelings of rejection and isolation.

Spatial layouts of purpose-built shelters, which accommodate asylum-seekers and refugees in container villages and apartments shared by two to six people (e.g., Figures 8 and 9), have interior spaces that are better suited for living compared to transformed warehouses. Although they offer higher levels of privacy, have fewer people sharing amenities, and allow some level of independence and autonomy, they are still referred to as "camps" by our contacts. The fact that they are purposebuilt for asylum-seekers keeps their inhabitants isolated from local Germans and from integrated co-ethnics in some sort of "ghettos" (Siebel, 2016), and confronts them with power structures (Kreichauf, 2018), with the management staff and security personnel. Of course, this varies in intensity when combined with other institutional arrangements mentioned above like their location, direct surroundings and being fenced off on the neighborhood level.

The spatial layouts decide the level of comfort and hence; the time spent in the accommodation, in which activities to participate-in and outside of the accommodation, and chances of interaction within the accommodation and neighborhood to build new social networks. They therefore contribute to the quality of life of asylumseekers and refugees, and to their integration processes.

Examples of other important non-spatial institutional arrangements are the demographic and social composi- 


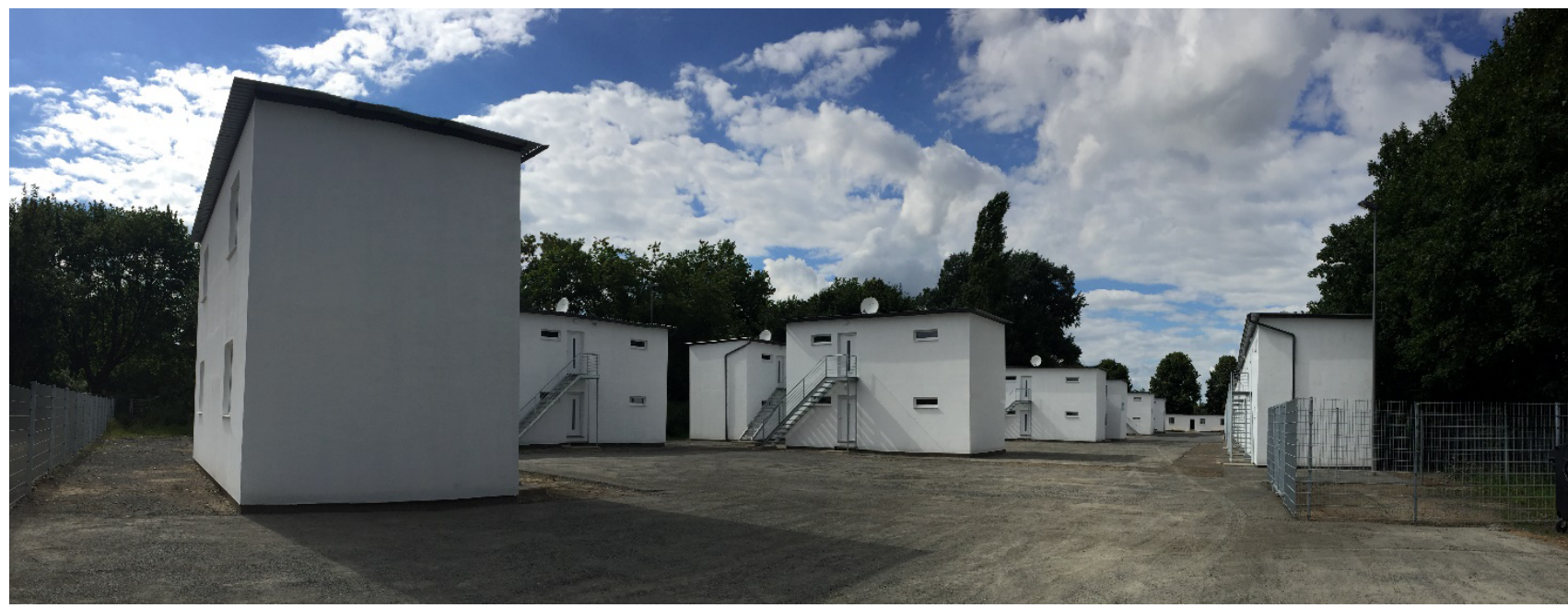

Figure 8. A purpose-built refugee accommodation compound for 200 people. The wooden-made structures resemble the design of modular container-villages and consist of two-floor structures with 2-4-person apartments. Source: author.

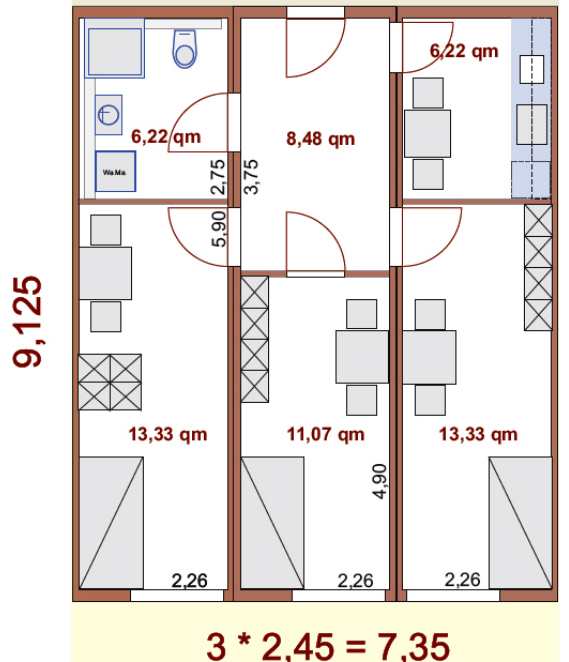

Figure 9. Floor plan of one apartment in a purpose-built, modular housing project for refugees. The apartments are designed for (up to) six people who share a bathroom, a kitchen and three bedrooms, furnished with bunk beds, a table, two chairs, and metal lockers. Source: Göttingen City website in 2016.

tions of inhabitants in accommodations, power and dependency structures (Kreichauf, 2018), accessibility to and qualification of management staff, social workers and translators, and the number of active volunteers involved in the daily lives of refugees.

Finally, it is worth mentioning here that the institutional arrangements are imposed by the system on asylum-seekers, who are expected to comply, especially if their social benefits depend on following the rules, like residing in the allocated accommodation. However, some asylum-seekers and refugees find ways to resist or adapt to the situation, to better suit their needs and priorities. This includes re-appropriating spaces in accommodations, staying with friends outside the accommodations, demonstrating against their accommodations, moving from the city, or even moving back to their accommodation, if their needs and priorities were not met in decentralized housing.

\subsection{Diversity and Personal Experiences of Asylum-Seekers}

Feedback from research participants showed the contrasting impressions, opinions and attitudes that asylumseekers have gathered towards their host cities or Germany as a host country. While some praised the welcoming culture and expressed gratitude for the services they receive, others-in the same cities and sometimes within the same accommodation-reported isolation and exclusion from services, rights or the job market, blaming this on municipal staff and German institutions and laws. Based on their experiences, some reported their desire to move to other cities, or leave the country as soon as they can, while others expressed their wish to build a future in that city. These contrasting cases indicate that the combination of institutional arrangements, their personal experiences and the relationships they developed in their host neighborhoods and cities in the first phase of their accommodation, played a role in the attitudes they developed towards the host cities and integration in general. This confirms both assumptions that the local strategies of reception and accommodation influence the trajectories of integration from day one. Those who had comfortable living situations, access to resources and volunteers who supported them and made them feel welcome presented positive views, which encouraged them to engage with and "work harder" towards integration. Others who were isolated, for example because of their accommodation's location, because of their low recognition profile (schlechte Bleibeperspektive), or because they belonged to a specific social or age group, had different experiences, which affected both their perspectives and attitudes towards integration. Of course, the very diverse personal backgrounds of asylum- 
seekers: gender, age, marital status, skills, languages, nationalities, legal statuses, Bleibeperspektive, education levels, lifestyles and so on are all important factors in their encounters and experiences, in the way they perceive and interact with their surrounding environment, and whether it facilitates or hinders integration. However, this very important aspect is beyond the scope of this article.

\section{Conclusions}

This article is based on research findings related to spatial aspects of refugee reception, accommodation and integration in the German experience by focusing on a mid-sized city in Lower-Saxony. The article argues for the importance of the local in the planning and implementation of integration strategies in an early phase of reception and accommodation, and for the importance of institutional arrangements of refugee accommodation in planning for long-term integration of refugees. The main arguments are summarized below.

\subsection{The Importance of the Local Level}

This article starts from the assumption that integration happens on the local level of a given host city, and more specifically on the level of the neighborhood, an assumption that is backed by the effects of the spatial institutional arrangements illustrated above. Therefore, and in order to plan for future integration of asylum-seekers; local strategies and planning should take into consideration the uniqueness of cities, their histories and demographic and cultural constructs, as well as those of the neighborhoods hosting refugee accommodations. Furthermore, the existing local needs for urban development, infrastructure and affordable housing should not be ignored in times of crisis. They should be integrated into emergency and contingency plans, while facilitating the participation of the local population as well as the affected refugees. This is especially important, where social groups compete for resources on the local level. Creating housing solutions for a specific group (e.g., refugees) can increase feelings of resentment and lead to protests by the other groups whose social housing needs were abandoned for many decades as budgets for social housing were reduced.

Working with the local civil society to identify innovative urban planning solutions, and suitable locations for refugee accommodations in empty and underused plots depending on local knowledge and cooperation (e.g., FindingPlaces partnership project in city of Hamburg; Colini \& Tsitselikis, 2017; Zanghi, 2016) can be a successful local strategy to involve the local population in planning for more welcoming and durable housing solutions. This could also contribute to reduction of possible resistance to municipal top-down refugee housing projects. This requires the decision makers to consider principles of urban planning and design to create new spaces and environments that can better facilitate integration processes and avoid feelings of abandonment by the locals, leading to anti-immigrant sentiments. In addition, enough attention should be paid to the status and capacity of local infrastructure and services (e.g., kindergartens, schools, and public transportation), and to plan for their improvement in case they are expected to serve a large group of new comers.

\subsection{Segregation/Integration}

The article's second assumption is that integration starts from day one of the arrival in a new country, city or neighborhood. Since most asylum-seekers are accommodated in collective accommodations in the first phase of their arrival, and for months or years to come, this article analyzed the local factors important for integration through the lens of refugee accommodations, mainly focusing on their spatial institutional arrangements. However, many of these institutional arrangements would still be relevant in later phases of housing.

Spatial segregation through the location of refugee accommodations is not the only factor that hinders possibilities of better integration. According to van Ham and Tammaru (2016), segregation patterns are linked to different geographical or spatial and temporal rhythms. These patterns affect different life domains of those affected:

Not just in terms of the neighborhoods they live in, but also in terms of who they live with, where they work, who they meet on their way to work, at work, in their leisure time, etc. Their residential neighborhoods alone do not capture the level of segregation the experience in their daily lives. (van Ham \& Tammaru, 2016, p. 956)

The article argues that the experiences that new arrivals face in the first phase of their reception and accommodation, and the relationships they build in their neighborhoods and host cities have a long-term effect on their lives later, and play a significant role in the way their impressions, aspirations and motivations develop along the way of their integration trajectories. Those who end up in a combination of institutional arrangements that facilitate building networks with co-ethnics and locals experience a faster process of integration than others who land in combinations of institutional arrangements that lead to segregated spatial or temporal rhythms.

These rhythms are affected by several spatial aspects of refugee accommodations, like their proximity to the city center, direct surroundings, size and spatial layouts, and whether they are centralized or decentralized. They are also affected by other institutional arrangements like their access to resources, services and to social networks, the possibility of encounter in neighborhood and city spaces, the demographic composition (nationalities, languages, ages, genders, legal statuses, marital statuses, 
etc.) of asylum-seekers in each accommodation, power and dependency structures, and the qualification of management staff, social workers, translators and volunteers. This is in addition to the highly diverse personal backgrounds and skills of asylum-seekers, which play a central role in their experiences and perceptions.

\subsection{Planning for Integration}

This article presented local factors significant for urban planning to include while preparing for the integration of refugees in European cities. It clarified that many urban planning decisions on the local level, especially since the beginning of the "refugee crisis" of 2015, were spontaneous, practical or ad hoc measures that were taken by a wide range of politicians and administrative departments of German municipalities, while facing a wide range of challenges on the local level.

The role of urban planners and architects was mostly physical not holistic and was introduced to the processin many cases-after the decisions on some spatial institutional arrangements e.g., locations and sizes of accommodations were already made. Sometimes, like the case of Frankfurt in (Schiller, 2018), these decisions were even made against the advice of urban planners. Therefore, this article does not address urban planners or their role since the beginning of the crisis, but focuses on relevant local spatial institutional arrangements, regardless of who makes the decisions. In that light, the article calls for a more holistic approach in planning for the future of reception, accommodation and integration. It also calls for a more substantial involvement of urban planners, while considering the local factors illustrated above; the city profile (social, cultural, economic, demographic, political, urban, potential investment etc.), the local challenges, and the effects of institutional arrangements on different domains of refugee lives, their social networks, and their trajectories of integration.

The article concludes that there are no "best solutions" that fit all refugees or all cities. Planning for integration is most effective on the local level, where refugees live and interact with their local environments, and where the local host community and refugees would have the possibility to participate in planning and decision-making. Based on a complex set of spatial and temporal factors, some of which are general and others are unique to specific cities and neighborhoods, different combinations of institutional arrangements can produce different results in different contexts on the city and neighborhood levels and should, therefore, be considered in their respective contexts. Finally, decision makers and planners on the city level should identify both short- and long-term solutions (Katz et al., 2016)-with well-considered institutional arrangements-to accommodate asylum-seekers and refugees in a context that could facilitate integration, avoid segregation and improve the resilience of European cities (Baléo, 2017), in the face of future crisis.

\section{Acknowledgements}

The author would like to thank Ms. Somayeh Chitchian for her invaluable support and feedback in the writing process.

\section{Conflict of Interests}

The author declares no conflict of interests.

\section{References}

Ager, A., \& Strang, A. (2008). Understanding integration: A conceptual framework. Journal of Refugee Studies, 21(2), 166-191.

Alba, R., \& Foner, N. (2014). Comparing immigrant integration in North America and Western Europe: How much do the grand narratives tell Us? International Migration Review, 48(S1), S263-S291.

Baléo, M. (2017). European cities and the refugee situation: A laboratory for affordable housing and urban resilience to future cities. Rueil-Malmaison: La Fabrique de La Cite.

BAMF. (2016). The stages of the German asylum procedure. An overview of the individual procedural steps and the legal basis. Nürnberg: Bundesamt für Migration und Flüchtlinge. Retrieved from www.bamf.de/ SharedDocs/Anlagen/EN/Publikationen/Broschueren/ das-deutsche-asylverfahren.pdf?_blob=publication File

BAMF. (2017). Das Bundesamt in Zahlen 2016: asyl, migration und integration [The Federal office in numbers 2016: Asylum, migration and integration]. Nürnberg: Bundesamt für Migration und Flüchtlinge. Retrieved from www.bamf.de/SharedDocs/Anlagen/ DE/Publikationen/Broschueren/bundesamt-in-zahlen -2016.pdf?_blob=publicationFile

Black, R. (2001). Fifty years of refugee studies: From theory to policy. International Migration Review, 35(1), 57-78.

Bommes, M. (2007). Kommunen und nachholende Integrationspolitik: Handlungsperspektiven und Handlungsspielräume [Local authorities and catching-up integration policy: Perspectives and scope for action]. In K. J. Bade \& H.-G. Hiesserich (Eds.), Nachholende Integrationspolitik und Gestaltungsperspektiven der Integrationspraxis [Catching-up integration policy and design perspectives in integration practice] (pp. 97-123). Göttingen: V\&R unipress.

Brezzi, M., Dumont, J. C., Piacentini, M., \& Thoreau, C. (2010). Determinants of localization of recent immigrants across oecd regions. Paris: OECD.

Castles, S., Korac, M., Vasta, E., Vertovec, S. (2002). Integration: mapping the field (Home Office Online Report 28/03). London: Home Office Immigration Research and Statistics Service.

Chin, R. (2007). The guest worker question in postwar Germany. New York, NY: Cambridge University Press. 
Christ, S., Meininghaus, E., \& Röing, T. (2017). Konfliktprävention in Unterkünften. Selbstverantwortung geflüchteter Menschen stärken [Conflict prevention in accommodations. Strengthening self responsibility of refugees] (BICC Policy Brief 3/2017). Bonn: Bonn International Center for Conversion.

Colini, L., \& Tsitselikis, K. (2017). Integration processes at city level: Hamburg, Ghent, Amadora. URBACT cities good practices. Urbact. Retrieved from urbact.eu/integration-processes-city-level-hamburgghent-amadora-urbact-cities-good-practices

Drieschner, F. (2016, April 25). Flüchtlingsunterkünfte: Wer protestiert warum? [Refugee accommodations: Who is protesting and why?]. DIE ZEIT. Retrieved from www.zeit.de/2016/17/fluechtlingsunterkuenf te-hamburg-proteste-blankenese-oberschicht

Engelmann, C. (2018). Die Organisation des Alltags in Gemeinschaftsunterkünften: Empirische Erkenntnisse zu Privatsphäre und dem Verhältnis PersonalBewohnerschaft [The organization of everyday life in refugee accommodations: Empirical findings to privacy and the relationship of staff-inhabitant]. FlüchtlingsforschungsBlog. Retrieved from fluecht lingsforschung.net/die-organisation-des-alltags-ge meinschaftsunterkunften

ESPON. (2015). Territorial and urban aspects of migration and refugee inflow (Policy Brief 2). Luxembourg: ESPON. Retrieved from www.espon.eu/sites/ default/files/attachments/Policy_brief_migration_ FINAL_151215.pdf

Esser, H. (2006). Migration, Sprache und Integration [Migration, language and integration] (AKIForschungsbilanz, 4). Berlin: Wissenschaftszentrum Berlin für Sozialforschung $\mathrm{gGmbH}$ FSP Zivilgesellschaft, Konflikte und Demokratie Arbeitsstelle Interkulturelle Konflikte und gesellschaftliche Integration-AKI.

EUROSTAT. (2016). Asylum in the EU member states: Record number of over 1.2 million first-time asylum seekers registered in 2015 (Newsrelease no. 44/2016). EUROSTAT.

Fonseka, M. L., \& McGarrigle, J. (2012). Generating interethnic tolerance and neighborhood integration in European urban space (Working Paper). Lisbon: Centro de Estudos Geográficos.

Geertz, C. (1998). Deep hanging out. The New York Review of Books, 45(16), 69-72.

Gesley, J. (2017). Germany: The development of migration and citizenship law in postwar Germany. Washington, DC: The Law Library of Congress.

GÖSIS. (2016). Stadt Göttingen: Bevölkerung 2012 bis 2016 [The city of Göttingen: Population 2012 to 2016]. Göttinger Statistisches Informationssystem. Retrieved from goesis.goettingen.de

Hess, S., Binder, J., Moser, J. (2009). No integration?! Kulturwissenschaftliche Beiträge zur Integrationsdebatte in Europa [No integration?! Anthropological contributions to the integration debate in Europe].
Bielefeld: Transcript-Verlag für Kommunikation, Kultur und soziale Praxis.

Hinze, A. M. (2013). Turkish Berlin: Integration policy and urban space. Minneapolis, MN: University of Minnesota Press.

Hooper, A. J. (1988). Planning and the control of development in the Federal Republic of Germany. The Town Planning Review, 59(2), 183-205.

Katz, B., Noring, L., \& Garrelts, N. (2016). Cities and refugees: The German experience. Washington, DC: Brookings.

Khamaisi, R. (2006). Planning and developing a new Palestinian urban core under conditional Israeli occupation: Ramallah City. Paper presented at the 42nd ISoCaRP Congress, Istanbul.

Kreichauf, R. (2018). From forced migration to forced arrival: The campization of refugee accommodation in European cities. Comparative Migration Studies, 6(7), 1-22.

Kronenberg, V. (2018). Integration vor Ort: Flucht und Migration als Herausforderung für die Kommunen: Bilanz und Perspektiven [Integration on the ground: Flight and migration as a challenge for local authorities. Balance and perspectives]. In Becker, M., Kronenberg, V., \& Pompe, H. (Eds.), Fluchtpunkt Integration: Panorama eines Problemfeldes [Focus point integration: Panorama of a problematic field]. Wiesbaden: Springer VS.

Landkreis Göttingen. (2018). Kreistag und Sitzverteilung [District assembly and seat distribution]. Landkreis Göttingen. Retrieved from www.landkreisgoettingen. $\mathrm{de} /$ staticsite/staticsite. . php ?menuid=64\&topmenu $=6$

Le Galès, P. (2003). Le retour des villes européennes: Sociétés urbaines, mondialisation, gouvernement et gouvernance [The return of European cities: Urban societies, globalization, government and governance]. Paris: Presses de Sciences Po.

Lindley, A. (2014). Crisis and migration. Critical perspectives. Routledge studies in development, mobilities and migration. New York, NY: Routledge.

Loch, D. (2014). Integration as a sociological concept and national model for immigrants: Scope and limits. Identities, 21(6), 623-632.

Mecheril, P. (2011). Wirklichkeit schaffen: Integration als Dispositiv [Creating reality: Integration as a dispositive]. Bundeszentrale für politische Bildung. Retrieved from www.bpb.de

Othengrafen, F. (2012). Uncovering the unconscious dimensions of planning: Using culture as a tool to analyse spatial planning practices. Farnham: Ashgate.

Pahl-Weber, E., \& Henckel, D. (Eds.). (2008). The planning system and planning terms in Germany: A glossary. Studies in spatial development (Vol. 7). Hannover: Verlag der ARL.

Penny, E. (2016). We do not have a refugee crisis. We have a housing crisis. Open Democracy. Retrieved from www.opendemocracy.net/can-europemake-it/eleanor-penny/we-don-t-have-refugee-crisis 
-we-have-housing-crisis

Poteet, M., \& Nourpanah, S. (2016). After the flight: The dynamics of refugee settlement and integration. Newcastle upon Tyne: Cambridge Scholars Publishing.

Ray, B. (2003). The role of cities in immigrant integration. Migration Policy Institute. Retrieved from www.migrationpolicy.org/article/role-cities-immigrant -integration

Renner, N. (2018). Die Wohnsitzauflage als Mittel deutscher Integrationspolitik? Das Beispiel Sachsen [The residence requirement as a means of German integration policy? The example of Saxony] (MIDEM-Policy Paper 01/18). Dresden: MIDEM Mercator Forum. Retrieved from forum-midem.de/ $\mathrm{cms} /$ data/fm/download/MIDEM_Policy_Paper_2018 -1_Wohnsitzauflage.pdf

Schiller, M. (2018). Deliberative democracy and betrayal: Urban planning, citizen involvement and the arrival of asylum seekers in a Frankfurt neighborhood. Unpublished manuscript.

Scholten, P., Baggerman, F., Dellouche, L., Kampen, V., Wolf, J., \& Ympa, R. (2017). Rotterdam. Policy Innovation in refugee integration. A comparative analysis of innovative policy strategies toward refugee integration in Europe. Rotterdam: Erasmus University Rotterdam.

Schönwälder, K. (2013). Integration; no integration? Worüber das Streiten (nicht) lohnt [Integration; no integration? What is (not) worth arguing about]. Migration und soziale Arbeit, 35(3), 217-221.

Siebel, W. (2016). Immigrant neighborhoods: An essential step towards integration. In P. C. Schmal, O. Elser, \& A. Scheuermann (Eds.), Making Heimat: Germany, arrival country (pp. 220-227). Ostfildern: HATJE CANTZ.

Stadt Göttingen. (2014). Konzept zur Wohnraumversorgung und Integration von Flüchtlingen in der Stadt Göttingen [Concept of housing provision and integration of refugees in the city of Göttingen]. Stadt Göttingen: Dezernat für Soziales und Kultur.

Stadt Göttingen. (2018a). Rat [City council]. GöttingenStadt, die Wissen schafft. Retrieved from www. goettingen.de/rathaus/politik/rat.html

Stadt Göttingen. (2018b). Demonstration auf der
Siekhöhe [Demonstration in Siekhöhe]. GöttingenStadt, die Wissen schafft. Retrieved from www. goettingen.de/aktuelles/2018-06-28/demonstrationauf-der-siekhoehe.html

Strubelt, W., Gatzweiler., H., \& Kaltenbrunner., R. (Eds.). (2000). Urban development and urban policy in Germany: An overview. Bonn: Federal Office for Building and Regional Planning.

The Federal Government. (2016). Integrationsgesetz in Kraft: Fördern und Fordern [The Integration Act in force: Support and demand]. The Federal Government. Retrieved from www.bundesregierung.de/ Content/DE/Infodienst/2016/08/2016-08-09-integra tionsgesetz/2016-08-09-integrationsgesetz.html

van Ham, M., \& Tammaru, T. (2016). New perspectives on ethnic segregation over time and space. A domains approach. Urban Geography, 37(7), 953-962.

Vertovec, S. (2011). Migration and new diversities in global cities: Comparatively conceiving, observing and visualizing diversification in urban public spaces (MMG Working Paper 11-08). Göttingen: Max-Planck-Institute for the Study of Religious and Ethnic Diversity.

Vertovec, S., Becker, S., Fleischer, A., Schader, M., \& Wari, S. (2017). Addressing the diversity of asylum-seekers' needs and aspirations. A Report to the Volkswagen Foundation (Working Paper 17-05). Göttingen: Max Planck Institute for the Study of Religious and Ethnic Diversity.

Wari, S. (2017). Palestinian Berlin: Perceptions and use of public space. Berlin: LIT Verlag.

Wendel, K. (2014). Unterbringung von Flüchtlingen in Deutschland. Regelungen und Praxis der Bundesländer im Vergleich [Accommodation of refugees in Germany. Comparison of regulations and practice in the federal states]. Frankfurt am Main: Förderverein PRO ASYL e. V.

Wiesemann, L. (2011). Public spaces, social interaction and the negotiation of difference. Paper presented at the International RC21 Conference, Amsterdam.

Wieviorka, M. (2014). A critique of integration. Identities, 21(6), 633-641.

Zanghi, A. (2016). The importance of arrival cities. CityLab. Retrieved from www.citylab.com/equity/ 2016/08/the-importance-of-arrival-cities/494189

\section{About the Author}

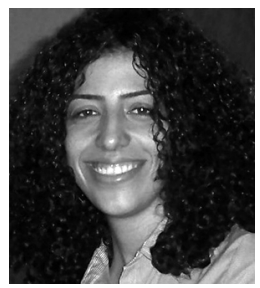

Shahd Seethaler-Wari (PhD) is a Post-Doctoral Researcher at the Department of Social and Cultural Diversity at the Max-Planck Institute for the Study of Ethnic and Religious Diversity. She has a PhD in Urban Planning and a master's degree in Urban Management from the Technical University in Berlin, as well as a bachelor's degree in Architectural Engineering from Birzeit University in Palestine. Her current research focuses on the role of urban planning and architecture in the daily lives of asylum seekers and their future trajectories. 